\title{
No More The Wasted Breed: Femi Osofisan's Vitriolic and Ideological Response to Wole Soyinka's The Strong Breed
}

\author{
C. O. Ajidahun ${ }^{1}$ \\ ${ }^{1}$ Adekunle Ajasin University, P.M.B. 01, Akungba-Akoko, Ondo State, Nigeria \\ Correspondence: C. O. Ajidahun, PhD, Adekunle Ajasin University, P.M.B. 01, Akungba-Akoko, Ondo State, \\ Nigeria. Tel: 234-803-392-7663 \& 234-805-801-7164. E-mail: jideajidahun@yahoo.co.uk
}

Received: May 2, 2012 Accepted: August 8, 2012 Online Published: August 30, 2012

doi:10.5539/ells.v2n4p9 URL: http://dx.doi.org/10.5539/ells.v2n4p9

\begin{abstract}
The paper is a critical inter-textual and a comparative study of Femi Osofisan's vitriolic and ideological response theme of the scapegoat to both texts and interrogates the divergence between the two texts, which is overtly in his No More the Wasted Breed to Wole Soyinka's The Strong Breed. The paper notes the centrality of the implied in the thematic analysis of the texts. Such disparity is influenced by the ideological perspectives of both literary giants and of course due to the generational gap between them. The paper juxtaposes the traditional perspective from which Wole Soyinka presents The Strong Breed with the Marxist perception which dominates Femi Osofisan's No More the Wasted Breed. Apparently, the strong belief of Wole Soyinka in the inviolability of the gods and in the irrevocability of destiny is unarguably well delineated, which Osofisan finds offensive, unpleasant and unacceptable. This is because, to Osofisan, the carrier motif, as portrayed by Wole Soyinka, is retrogressive and oppressive, whereas man should be allowed to hold his destiny in his hands. The paper finally captures Osofisan's belief that the development and the cleansing of the society should be seen as a collective responsibility of everybody and not the oppressive tasks of a few breeds that have been destined for destruction by the gods.
\end{abstract}

Keywords: Soyinka, Osofisan, carrier motif, scapegoat, ideology

\section{Introduction}

The Nigerian writers in the pre-independence era and in early post-independence period, who are tagged as the old generation of Nigerian writers, are primarily concerned with the distortion of their cultures by the colonial masters. Chinua Achebe, for instance, says he uses his literature essentially for didactic reasons to let the whole world know that Africans and indeed the Igbo people did not come in contact with civilization and culture for the first time when they were colonized. As a result of their exposure to the Western ideas, the literature of this old generation of writers was essentially to protest against the Western prejudices. That is why Egharevba (1987) says that

Such exposure can at worst bring out in the writers, slavish imitation of the style and theme of the Metropolitan country, and at least induce protest whereby the writers use materials from their culture to prove positive an otherwise negatively held view about their society...their early pre-occupations consist of a reworking of their societal myth as a means of portraying a moral value needed by the society. (p.26)

The colonial masters were of the view that Africans never had culture and even if they ever had, it was barbaric, crude and uncivilized. Wole Soyinka, Chinua Achebe and others who belong to this group of old generation of Nigerian writers see themselves as agents of cultural change and values. To them, literature must be used to re-write their history and correct the colonial distortions of their cultural heritage. This then helps our understanding of Wole Soyinka's preoccupation with myth and ritual. This view is supported by Egharevba (1987) when he says that Wole Soyinka 'relies on the ideological framework of Yoruba mythology from which he projects a vision that out spaces ethnicity.'

With the Nigerian independence in 1960, the expectation was very high that the political class would bring the desired positive changes in the society. Unfortunately, according to Osofisan (2001), Soyinka was 'one of the first to foresee the squalid betrayal which would follow the opening rituals of Independence'. (p.8). To Soyinka therefore, he belongs to a wasted generation. That is why Osofisan (2001) says Soyinka's "writings invariably 
conclude in a grim and somber epistemology, offering a bleak picture, which is only the mirror of history as he and his contemporaries have lived and experienced it' '(p.10). One is therefore not surprised at the preponderance of references to wasted breed in Wole Soyinka's dramaturgy. It is an expression of his frustration with the ruling class.

Femi Osofisan, on the other hand, belongs to the new generation of Nigerian writers immediately following Wole Soyinka in the early 1970's. To them, independence has fetched them nothing. Their hopes have been dashed as an independent nation. The desire to liberate the masses from the economic exploitation of the oppressive ruling class continues to be their preoccupation. They are not concerned with the cultural renaissance, which is the focus of the earlier writers. They are concerned with the economic survival, equity, justice end to corruption, nepotism, oppression and other social vices plaguing the Nigerian society. Their views are therefore more radical than the views of their earlier writers whose interest is purely cultural. Enekwe (1978) confirms that the works of these young writers contain

An intensification of the critical spirit, an urge to overhaul the foundations on which the old social outlook was erected, and consequently an energy directed at creating a new mythology that would offer the projected or emergent society as a firmer road to self-realization than can be found in the older generations. (pp.118-136).

These writers reject the tragic vision expressed in the works of their predecessors because such works are incapable of raising the revolutionary impulse and consciousness of the masses. Both generations of writers utilize materials from oral literature to realize their visions. Both Soyinka and Osofisan address the theme of scapegoat and ritual in their texts. They delve on the same materials from oral literature but they differ in their conceptualizations and perspectives of the myth of the theme of the carrier because of their different ideological leanings. That is why Morosetti (2010) says that:

The eventual portraits of Nigeria that the two authors offer is indeed that of a "sow that repeatedly devours her own piglets" i.e. an increasingly violent and chaotic society, but in all this folly the reasonable logic that Soyinka and Osofisan support is that of a clear distinction between "true" and "false" villains. (p.1)

The observation made by Morosetti (2010) agrees with the earlier submission of Olaiya (2006) that the two plays, which basically focus on the myth of the carrier in Nigeria:

Illustrate the conscious fragmented remembering and the intense politics of selection and exclusion involved in the unpacking of national myths. The differing excuses in mythoclasm involved in the way they use myth to interrogate the Nigerian State constitute one of the enduring legacies of colonialism. (p.1)

It is against this background that we shall examine Femi Osofisan's No More the Wasted Breed as a direct, stupendous and vitriolic response to Soyinka's The Strong Breed.

\section{Discussion}

Soyinka, in The Strong Breed and in several of his plays, has portrayed the need for the society to be regenerated and that rebirth and regeneration can only be achieved through the offering of a carrier. That is why Soyinka's carrier motif or the theme of the scapegoat runs through a number of his plays such as The Bacchae, where Pentheus is torn into pieces by the Maenads on mountain Kithairon "as an embodiment of Dionysus who was torn to pieces by the Titan; and by his death he purges the guilt of Thebes for its failure to recognize the new, god, Dionysus" (Maduakor, 1987).

Soyinka, as a literary giant uses the drama medium to depict that, 'rites, ceremonials and rituals' are indispensable and inevitable metaphors for the drama of life. According to Soyinka (2001, p.108):

In The Strong Breed, for instance, I talk about the ritual of purification at the end of the year, which again is tied up with the whole business of sacrifice, of self-sacrifice, the acceptance of the role of the carrier in society on whatever level... the fact is that there are beings in society who accept the role of sacrifice."

In The Strong Breed for instance, Soyinka narrates the story of Emma who resides in a strange village that is under siege. It is plagued with evils of all proportions. A stranger is thus required, according to tradition, to bear the evils of the village and thus save it from the impending doom. Emma refuses to leave the village before the New Year's Festival begins at night despite Sunma's repeated appeals. Sunma, who works for Emma in his hut, does not hide her revulsion against the cruel and dastardly cultural practices of her village. Even her father Jaguna notices Sunma's vehement and passionate rebellion. Emma comes from the lineage of the strong breeds, which have been naturally marked as carriers. To justify this, Soyinka, through the use of flashbacks, shows us the images of Emma's father and Omae his wife who dies during child birth as it is typical of all females in the lineage of the strong breeds. According to Buchanan (1984, p.15): 
Part of the curse of being one of the "strong breed" is that one's wife must always die in giving birth to one's male child. This strange certainty is perhaps a sign that Soyinka believes that the close familial and tribal ties that Sunma being a woman, must value above all else (as she herself admits) vanish at the appearance of a more universal other-directed, multicultural conception of human identity embodied by the "strong breed" who define themselves as outsiders much like the osu in Achebe's fiction.

Being an Ifada naturally becomes the right candidate for the sacrifice. Oroge observes that the seeming love shown to outsiders and visitors like the helpless Ifada is a devilish device for capturing their victims:

No one in his senses would do such a job. Why do you think we give refuge to idiots like him? We don't know where he came from. One morning, he is simply there, just like that. From nowhere at all. You see, there is a purpose in that. (p.254)

To Emma, it is useless and degrading to force Ifada to be the carrier since he is unwilling: "In my home, we believe that a man should be willing" (p.252). This eventually makes Emma to substitute himself for Ifada. Emma finally fulfils his destiny as a carrier in a strange land. "Emma is thus portrayed as a type of Christ because he is both a teacher and healer and sacrifices his life to an insensitive village. Emma's father who is also a carrier sacrifices his life". Emma is thus offered as the carrier. This supports the views of Ogunba (1975) when he says that 'being a member of the strong breed, Emma possesses a peculiar kind of suffering which begins at birth, is enshrined in his system and thus goes through life groping towards a catastrophic end'. (p.155). An atmosphere of doom pervades Soyinka's text. This is Soyinka's 'belief in the irrevocability of the destiny of the human being'. According to Jones (1973, p. 51 and p.54):

Emma's humanity is in contrast to the brutal callousness of the village. He is a moral force without which the village would remain unregenerate in spite of the ritual of an annual sacrifice... But Emma is also a man. As a son and a pupil, he has relations with a father and his tutor. As a lover and husband he suffers the agony of losing his wife. He is human enough to prefer a quiet life to a life of self-sacrifice, but eventually an inner urge which he is unable to resist drives him on to accept the burden of sacrifice. He cannot escape this role because he is of the strong Breed.

But Osofisan rejects the position of Soyinka on the fatalistic destiny of the strong breed, which he sees as a triumph and vindication for the oppressors. Osofisan in Olatunde (1983) says:

Soyinka calls them (heroes) in the "Strong Breed" and I call them the "Wasted Breed". He sees them as heroes and I see them as victims, and the play, that's why it doesn't mean any tragedy. I deliberately wrote it in answer to his (Soyinka's) own position. People who are carriers... are deliberately made to carry the sins of society. Okay, so it has a lot of valour, a lot of bravery, but for what purpose? I think they are being cheated. Let each man carry the burden of his own sin. It's part of the ideology of the ruling class, that they should indoctrinate these people to like it. (p.158)

In No More the Wasted Breed, Osofisan employs the mythos-ritual systems to mirror the contemporary issues of oppression, injustice, exploitation and the call for a revolt. Here in the play, the human and the divines are brought together. Obviously, Osofisan appears to have reworked the myth of Olokun and Yemoja where the two deities are traditionally regarded as husband and wife.

Olokun is depicted as the archetype of justice while Elesu, the goddess of vengeance is portrayed according to Eshiet (1989) as "a metaphor for the totality of vice and villainy in African cosmogony and metaphysical system" (p.34). Despite the appeal of Olokun, Elusu insists on destroying and plaguing the land through flooding, epidemics, sickness and death because the people have neglected her for twenty five years. This is similar to the anger of Yemosa against the people of Aiyedade in Another Raft because the people of the town fail to offer sacrifices to the goddess.

Biokun, at the beginning of the play is seen carrying a sacrifice to the goddess Elusu because his son, Erindo has taken ill and all efforts to cure him have failed. The boy's ailment appears to have been provoked by the gods. Biokun needs to placate the goddess before his son can be cured. Saluga, a close friend and co-fisherman with Biokun, already a disillusioned man opposes Biokun's move. To him, the deities are irrelevant and ineffectual. Togun the priest already senses the state of mind of Saluga and knows that he will turn Biokun's mind against the deities and eventually prevent Biokun from placating the gods through the sacrifice.

The gods discover a mole on Biokun's chest which already marks him down as the carrier for the village. Meanwhile, Olokun has already revealed to Biokun that his father, Osoosi is the last carrier and that during a ritual process, a woman rushes out of the reeds and holds on to him and thereby contaminates the tradition. The 
woman is said to have been stoned to death while Biokun's father never returns home. The gods take him because he has destroyed their cult.

Since Biokun is from the family of carriers, it is now his turn to serve as carrier for the evils of the village. The gods want their cult restored so that the flooding and the plague can stop. Biokun is persuaded by the gods to offer himself as a sacrifice. Saluga counsels his friend against yielding to the demand of the gods: "Don't throw your life so uselessly... You and me, we've always asked that these old customs be discarded." (p.104)

To Biokun: It's not my life. It's just a trip across the water". Saluga refuses to be deceived and tells Biokun: "Use your brain Biokun! It's all a trick, can't you see?" (p.105). According to Ibitokun (1995, p.88): "use your brain." Saluga's statement "evokes dialectical reason, the faculty which dissolves the obscurantism of hideous myths." This is in tandem with the submission of Sandra (1996) that:

The Osofisan's script breaks with the transcendental mode that locates man's identity in some eternal essence. It argues instead for a materialistic perspective that emphasizes the social, economic, historical determinants of human identity. Yet in declaring rejection, the play creates for itself a space not in opposition but rather in proximity to the Soyinka text. (p.13)

Osofisan identifies with the poor and the oppressed in the society and wonders why they are usually called upon to sacrifice their lives at the expense of the rich. This is typical of Marxist ideology, which Osofisan's text represents, whereas Soyinka in The Strong Breed depicts the scapegoat principle, which is typical of the annual ritual of the traditional riverine people of Nigeria in particular. Speaking through Saluga, his mouthpiece, he says:

Tell me, why is it always us who give our lives? Why is it always the poor who are called to sacrifice? Why is it always the wretched, never a wealthy man, never the son of a king, who is suddenly discovered to bear the mark of destiny at difficult moments, and pushed on to fulfill himself in suicidal tasks? Why?... And who decided that chest moles are the mark of identify for carriers? Why not fat cheeks like yours for instance? Or a rotund overblown belly? I would have thought that a more juicy meal for your cannibal gods. (p.105)

Saluga confronts the gods and accuses them of wickedness. He wonders why they are always on the side of the oppressors. Saluga insults Elusu by calling her that old hag. Elusu is thus provoked and therefore attacks Saluga that he crashes to the ground and he begins to scream. In the midst of pains, he says, "I am not afraid! I have no respect for gods who feed on their worshippers" (p.107). Saluga later dies.

Suddenly, the eyes of Biokun become opened and he begins to chide the gods:

I was blind, just like my father... But my eyes are clear now... What is justice, when you hack a tree down and blame the handle of the axe? You complain of pollution, but who brought the ships of merchandise from across the ocean to our shore? You complain of being abandoned, but who brought the predators who impoverished our people and turned them into grovelling slaves? Did our conquerors not come across your seas, Olokun? Did they not berth in your waters, goddess?... Only a happy people pay homage to their gods. We fed you with the best of our seasons, praying for peace and abundance. But instead, you brought us the white slavers, who carried off our best men to the far plantations. To anguish and humiliation. They rode on your shoulders and they brought the terror of guns, the corruption of cowries, they brought their venereal diseases. And now they have seized control of the mainland over there, have seized our richest lands... What do you do, goddess?... Those are your friends, the ones you protect... But we're numerous and nameless, like the sand of the beach, we're wretched and expendable. A wasted breed. (pp.107-109)

The gods are completely overcome with shame at the words of Biokun. They therefore decide to withdraw and allow the people to have their freedom. As Elesu sings, Saluga is revived. Life is now restored. No more floods and the children no longer die. This is what Saluga describes as "It's a new world! The poor shall raise their heads! Men shall be free" (p.100).

This is a new generation. The message is now clear as Saluga tells Togun what the people need:

We'll teach you what to preach, Togun, if you're willing, we need tongues to rouse our people up into action, to build firmer sand barriers against flood, to reclaim more land from the sea, so we can grow food. (p.110)

The gods finally withdraw to the waves since men have become the masters of their own fate. Writing from the Marxist perspective, the message of Osofisan is clear; man's destiny is in his hands. According to Tomoloju $(1984$, p.5) "the gods you speak of are in your muscles, not just in your lips! They are yours to control. This is the reality with the contemporary playwrights' bearing with myth..." The people must therefore resist 
oppression from the ruling class and fight for their liberty even if it means dying for it. He wonders how a whole family can be destined for destruction.

Osoosi, Biokun's father dies while performing his duty as a carrier. Biokun's mother is killed for toughing a carrier. His only son, Erindo born after ten years of barrenness is suddenly struck with a disease. And now they demand for the life of Biokun. Besides, Saluga has no child. The whole land is completely devastated by the activities of the gods. According to Okafor (1996, p. 125):

The playwright goes beyond using dramatic characters to discuss the exploitation of people by the gods. He allows the viewing audience to witness exploitation themselves through the gruesome experience of play-within-a-play. The callousness and arrogance of the deity gleefully watching the play-within-a-play contrasts with the cathartic effect of the scene on the audience. They witness how the emotions, hope, and aspirations of ordinary people are manipulated and destroyed by capricious supernatural beings even as those beings sneer at the scene. While the goddess uses the scene to demonstrate the power of the gods, and the need for Biokun to tread in his father's footsteps, the sensitive Saluga thinks otherwise...The play-within-a-play underscores the need for change in the relationship between gods and men. Its use to re-enact history and make it functional in dealing with the present situation calls to mind Osofisan's The Chattering and the Song in which play-within-a-play is used to confront contemporary reality.

The play has a very significant relevance to the present day reality, especially in the contemporary socio-political and socio-economic structures of the society. The relevance of the play has been mentioned by Ibitokun (1995) when he opines that:

Saluga is a new breed who takes up arms against the various systems of pain, oppression and buffooneries such as we witness in most of the contemporary governments in Africa where youths are conscripted to lives of waste: neo-colonialism, imperialism, apartheid, and recurrent beginnings resultant from military coups. The myth which swaddles Biokun and Saluga, from which, now as critical adults, they struggle to liberate themselves, is the home-brewed religious version of those my satisfactory foreign ideologies. The will to live, to be free, to be accountable only to oneself, to sip the joys of life, like those self-styled super structural black predators, cronies and stooge of our times, is powerfully highlighted by the duo, especially by Saluga. (p.89)

The evils currently plaguing the African society can only be wiped out through the collective responsibility of the people and not through a single individual who is destined to die for the societal ills. The people have to be determined to die for the societal ills and also break from the unnecessary romance with the ruling class, the state and the bourgeoisie who are the oppressors. The will to survive, therefore, belongs to man and not to the gods'. No forces on earth can stop the movement of a people determined to fight against oppression and injustice.

The victory of Saluga and Biokun is similar to the triumph of the Yungba-Yungba group in Yungba-Yungba and the Dance Contest, The Farmers' Movement in The Chattering and the Song. The victory is achieved because the people are determined. Revolution will come and sweep away oppression, injustice, social inequality through the determined and collective will of the masses. The waves of revolution that blew across some parts of Northern Africa that swept away the tyrants and dictators in power for decades became successful as a result of the resolve and determination of the people.

To Osofisan, the gods are metaphors for oppression, while the carriers are the oppressed in the society who have been brainwashed and indoctrinated to accept their fate that they have been destined to remain poor and wretched all their lives and that they should be ready to be offered as sacrifices for the enrichment of the rich. This is unacceptable to Osofisan, who was once a victim of poverty and dehumanization but who has risen to the zenith of his career through dint of hard work, perseverance and patience rather than being a carrier. And he has deployed successfully his literary creativity and intellectual sagacity appropriately to make that point unequivocally.

\section{References}

Buchanan, B. (1984). "The Last Proof of the Human in You": Wole Soyinka and the Oedipus Myth. Retrieved from Freedomload.is/doc/Soyinka-main-concerns-are-with-the-collisions-btw-divine-and-5591792.html. http://www.goggle.com. pp. 14-15.

Egharevba, Chris. (1987). The Carrier Ritual as Medium of Vision in Nigerian Drama: The Examples of Soyinka and Osofisan. In Ernest Emenyonu (Ed.), Critical Theory and African Literature. Ibadan: Heinemann. pp. 25-36.

Enekwe, Essien. (1978). Interviews granted at Ibadan. (Unpublished). Quoted by Olu Obafemi in 'Revolutionary Aesthetics in Recent Nigerian Theatre'. African Literature Today, 12, 118-136. 
Eshiet, I. J. (1989). The Social Relevance of Femi Osofisan. In Ernest Emenyonu (Ed.), Literature and National Consciousness. Ibadan: Heinemann.

Ibitokun, B. M. (1995). The Assertion of Will: The Socio-Political Perspective. In B. M. Ibitokun (Ed.), African Drama and the Yoruba World-View. Ibadan: Ibadan UP. pp. 83-97.

Jones, Eldred Durosimi. (1973). The Writing of Wole Soyinka. London: Heinemann.

Maduakor, O. (1987). Wole Soyinka: An Introduction to His Writing. Ibadan: Heinemann.

Morosetti, T. (2010). The Sow That Repeatedly Devours Her Own Piglets: Villains on the Nigerian Stage. Paper Presented at the 2nd Global Conference on "Villains and Villainy" in Oriel College, Oxford from 14 to 16 September. 1-6. Retrieved from www.inter-disciplinary.net/at-the-interface/evil

Ogunba, Oyin. (1975). Movement of Transition. Ibadan: Ibadan University Press.

Olaiya, K. (2006). Memory Fragments and the Unpacking of Natural Myths in Wole Soyinka's The Strong Breed and Femi Osofisan's No More the Wasted Breed. Paper Presented at the Chimalpahin Conference on "Colonial and Post Colonial Remembering" in Mexico City from 16 to 18 October. Retrieved from www.enkidumagazine.com/events/chimal[ahin/abstracts/A

Olatunde, Laniyan Simon-Peter. (1983). The Use of Myth and History as Social Commentary in the Works of Wale Ogunyemi and Femi Osofisan. An Unpublished M.A. Thesis. Department of Theatre Arts. University of Ibadan.

Okafor, Chinyere. (1996). Theatrical Negotiation of Transformation in No More the Wasted Breed. In Muyiwa Awodiya (Ed.), Femi Osofisan: Interpretive Essay I. Lagos: Centre for Black and African Arts and Civilization. pp. 119-128.

Osofisan, Femi. (1976). The Chattering and the Song. Ibadan: UP.

Osofisan, Femi. (1983). Morountodun and Other Plays; Incl. No More the Wasted Breed and Red is the Freedom Road. Lagos: Longman.

Osofisan, Femi. (1989). Another Raft. Lagos: Malthouse Press.

Osofisan, Femi. (1993). Yungba Yungba and the Dance Contest. Ibadan: Heinemann.

Osofisan, Femi. (2001). Insidious Treasons: Drama in a Postcolonial State. Ibadan: Opon Ifa Readers.

Richards, Sandra. (1996). Ancient Songs Set Ablaze: The Theatre of Femi Osofisan. Washington: Howard UP.

Soyinka, W. (1973). The Strong Breed. Oxford: Oxford UP.

Soyinka, W. (1975). The Bacchae of Euripides. London: George Allen and Unwin Ltd.

Soyinka, W. (2001). Conversations with Wole Soyinka. (Ed. By Biodun Jeyifo). Jackson: Mississippi UP. pp. 108-122.

Tomoloju, Ben. (1984). A Review of Morountodun and Other Plays. The Democrat Weekly, May 13, 5. 